2. Radwaner BA, Geringer R, Goldmann AM, et al. Left main coronary artery stenosis following mediastinal irradiation. Am J Med. 1987;82:1017-20

3. Cohn KE, Stewart JR, Fajardo LF, et al. Heart disease following radiation. Medicine (Baltimore). 1967;46:281-98.

4. Jaworski C, Mariani JA, Wheeler G, et al. Cardiac complications of thoracic irradiation. J Am Coll Cardiol. 2013;61:2319-28.

5. Veeragandham RS, Goldin MD. Surgical management of radiation induced heart disease. Ann Thorac Surg. 1998;65:1014-9.

6. Chang AS, Smedira NG, Chang CL, et al. Cardiac surgery after mediastinal radiation: Extent of exposure influences outcome. J Thorac Cardiovasc Surg. 2007;133:404-13.

7. Alsara O, Alsarah A, Kalavakunta JK, et al. Isolated left main coronary artery stenosis after thoracic radiation therapy: To operate or not to operate. Case Rep Med. 2013;2013:834164, doi: 10.1155/2013/834164. Publicación electronica: 12 Dic 2013.

8. Siregar S, de Heer F, van Herwerden LA. Cardiac surgery in patients irradiated for Hodgkin's lymphoma. Neth Heart J. 2010;18:61-5.

9. Wu W, Masri A, Popovic ZB, et al. Long-term survival of patients with radiation heart disease undergoing cardiac surgery: A cohort study. Circulation. 2013;127:1476-85.
10. Schomig K, Ndrepepa G, Mehilli J, et al. Thoracic radiotherapy in patients with lymphoma and restenosis after coronary stent placement. Catheter Cardiovasc Interv. 2007; 70: $359-65$.

Alejandro Gutiérrez-Barrios*, Santiago Camacho-Freire, Antonio Agarrado-Luna, Miguel Alba-Sánchez, Sergio Gamaza-Chulián, Javier León-Jiménez, Jesús Oneto-Otero y Javier Benezet-Mazuecos

Servicio de Cardiología, Hospital de Jerez de la Frontera, Jerez de la Frontera, España

* Autor para correspondencia: Calle Barrón n. ${ }^{\circ} 20$ (Urbanización Valdelagrana), Puerto de Santa María (Cádiz), CP 11500, Teléfono: +620 688877 .

Correo electrónico: aleklos@hotmail.com

(A. Gutiérrez-Barrios).

http://dx.doi.org/10.1016/j.acmx.2014.05.003

\section{Guidewire protection for a valve-in-valve transcatheter aortic valve implantation procedure with high-risk for coronary obstruction}

\section{Protección coronaria con guía para un procedimiento de alto riesgo de obstrucción coronaria tras implantación de válvula aórtica transcatéter}

Transcatheter aortic valve implantation (TAVI) has emerged as an effective option for the treatment of high-risk patients with native aortic stenosis. ${ }^{1}$ Furthermore, there has been a rapid expansion of TAVI toward a larger spectrum of patients, such as those with degenerative surgical bioprosthesis. ${ }^{2}$ While the procedure is successful in most cases, some life-threatening complications such as coronary obstruction still remain. ${ }^{3,4}$ Anatomical factors such as low lying coronary ostia and shallow sinus of Valsalva have been associated with a higher risk for coronary obstruction, ${ }^{3}$ but no specific preventive measure has been established to date for this life-threatening complication. To this effect, we describe the case of a patient considered at high surgical risk for conventional aortic valve replacement in whom TAVI was carried-out. Due to high-risk features for coronary obstruction we decided to protect the left main coronary artery with a coronary guidewire prior to valve implantation.

An 80-year-old frail male presented to the ER with rapidly progressive dyspnea (NYHA class III-IV) and chestpain. He had surgical aortic valve replacement with a 23-mm Freestyle stentless bioprosthetic valve performed 14 years earlier with concomitant coronary artery bypass graft (CABG). An echocardiogram showed a mild stenosis of the bioprosthesis (peak gradient: $35 \mathrm{mmHg}$; mean gradient: $15 \mathrm{mmHg}$; aortic valve area: $0.96 \mathrm{~cm}^{2}$ ), severe regurgitation due to leaflet rupture and reduced left ventricular ejection fraction (currently 35 vs. 50\% 6 months earlier). A coronary angiography showed a severe lesion in the proximal left anterior descending artery (LAD). Due to the high-risk profile of the patient (logistic EuroSCORE: 20\%; STS-PROM: 10\%), the Heart Team opted for TAVI treatment, and the treatment of the LAD stenosis with a drug-eluting stent was successfully performed before the TAVI procedure. Angiographic computed tomography prior to TAVI showed a sinus of Valsalva diameter of $28 \mathrm{~mm}$ and height of the RCA and left main (LM) of 10 and $8 \mathrm{~mm}$, respectively (Fig. 1). Taking into consideration these high-risk anatomical characteristics and the presence of a previous stentless bioprosthesis, we decided to perform the TAVI with left main guidewire protection.

The TAVI procedure was performed through transfemoral approach, under general anesthesia, with fluoroscopy and echocardiographic guidance. Before any maneuver at the level of the aortic valve, an extra-support Wiggle guidewire (Abbott Vascular, Santa Clara, CA, USA) was placed in the distal LAD (Fig. 2). The deployment of a 23-mm SAPIEN $X T$ valve (Edwards Lifesciences Inc., Irvine, CA, USA) valve was performed under rapid pacing with the slow inflation technique, ${ }^{5}$ and with the valve slightly more ventricular (Fig. 2). Immediately after valve deployment the patient presented ST-segment elevation and severe persistent hypotension. Using a DOC extension to the Wiggle guidewire, an Extra BackUP 6Fr guiding catheter was advanced and the contrast injection showed obstruction of the LM ostium (Fig. 2). A pre-dilatation with a $4.0 \times 12 \mathrm{~mm}$ balloon (Sprinter Legend RX-Medtronic, Minneapolis, MN, USA) restored the coronary flow and pressures, followed by a Promus Element stent (Boston Scientific, Natick, MA, USA) $4.0 \times 12 \mathrm{~mm}$ implantation in the LM, partially protruding into the aorta. 


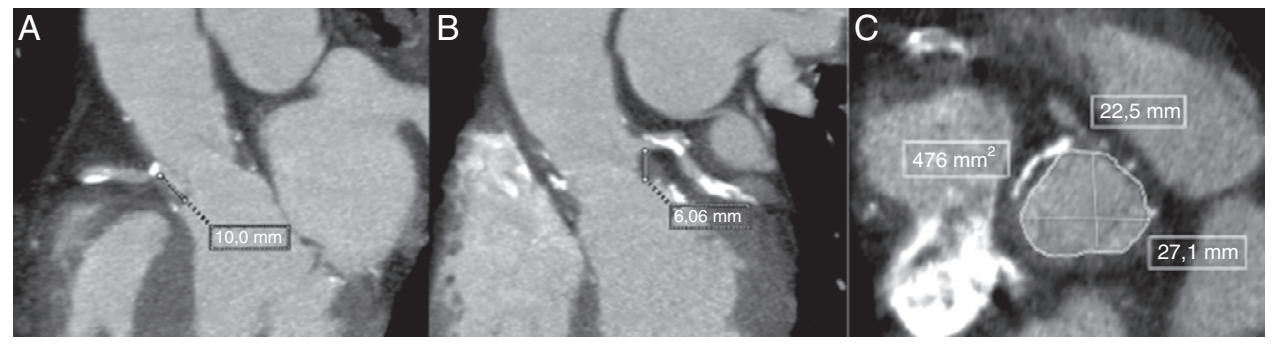

Figure 1 Multi-detector computed tomography (MDCT) evaluation pre-TAVI showing the measurements in the long-axis view with a height of $10 \mathrm{~mm}$ for the right coronary artery $(\mathrm{A})$ and $8.06 \mathrm{~mm}$ for the left coronary artery (B). Measurements of the sinus of Valsalva were obtained from the mean of the maximum and minimum cross-sectional diameters in the short-axis view (C).

A final angiogram showed (Fig. 2) no significant residual coronary stenosis and coronary flow TIMI 3. Following the procedure, the patient had an excellent recovery and was discharged four days later. At 6-month follow-up the patient was in NYHA class I, with a normofunctioning valve (mean gradient $20 \mathrm{mmHg}$, valve area of $1.1 \mathrm{~cm}^{2}$, and mild paravalvular leak), and left ventricle ejection fraction of $55 \%$. Cardiac CT demonstrated the permeability of the coronary stent with a good position of the SAPIEN XT valve.

Coronary obstruction following TAVI presents a high mortality rate $(\sim 50 \%),{ }^{3,4}$ and is usually caused by the displacement of an aortic valve leaflet toward the coronary ostium, with an incidence of up to $3.5 \%$ in the context of $\mathrm{TAVI}$ in patients with prior surgical bioprosthesis ("valve-invalve"' - ViV-TAVI). ${ }^{2}$

The presence of low-lying coronary ostia and shallow sinus of Valsalva were identified as potential risk factors for this complication in our case. ${ }^{3}$ The cutoffs determined by computed tomography, as of increased risk, are a LM height $<12 \mathrm{~mm}$ and a sinus of Valsalva less $<30 \mathrm{~mm}$. ${ }^{4}$ Severe persistent hypotension, which is present in $\sim 70 \%$ of patients, and ST-segment changes immediately post-TAVI may establish the diagnosis in some cases. ${ }^{3,4}$ It has been shown that either crossing the obstruction with the guidewire and/or advancing a stent through the guidewire may be challenging in such cases. ${ }^{3,4}$ It has been therefore suggested that leaving a preventive stent in the coronary, together with the guidewire, might potentially avoid the difficulty in crossing with the stent throughout the valve stent frame. ${ }^{6}$

In conclusion, coronary obstruction following TAVI, although rare, is a potential fatal complication. Some clinical and anatomical characteristics may determine a higher risk for its occurrence. In such patients, the preventive placement of a coronary guidewire may be advisable to promptly depict this complication and proceed with percutaneous coronary intervention. Future studies, with a larger num-
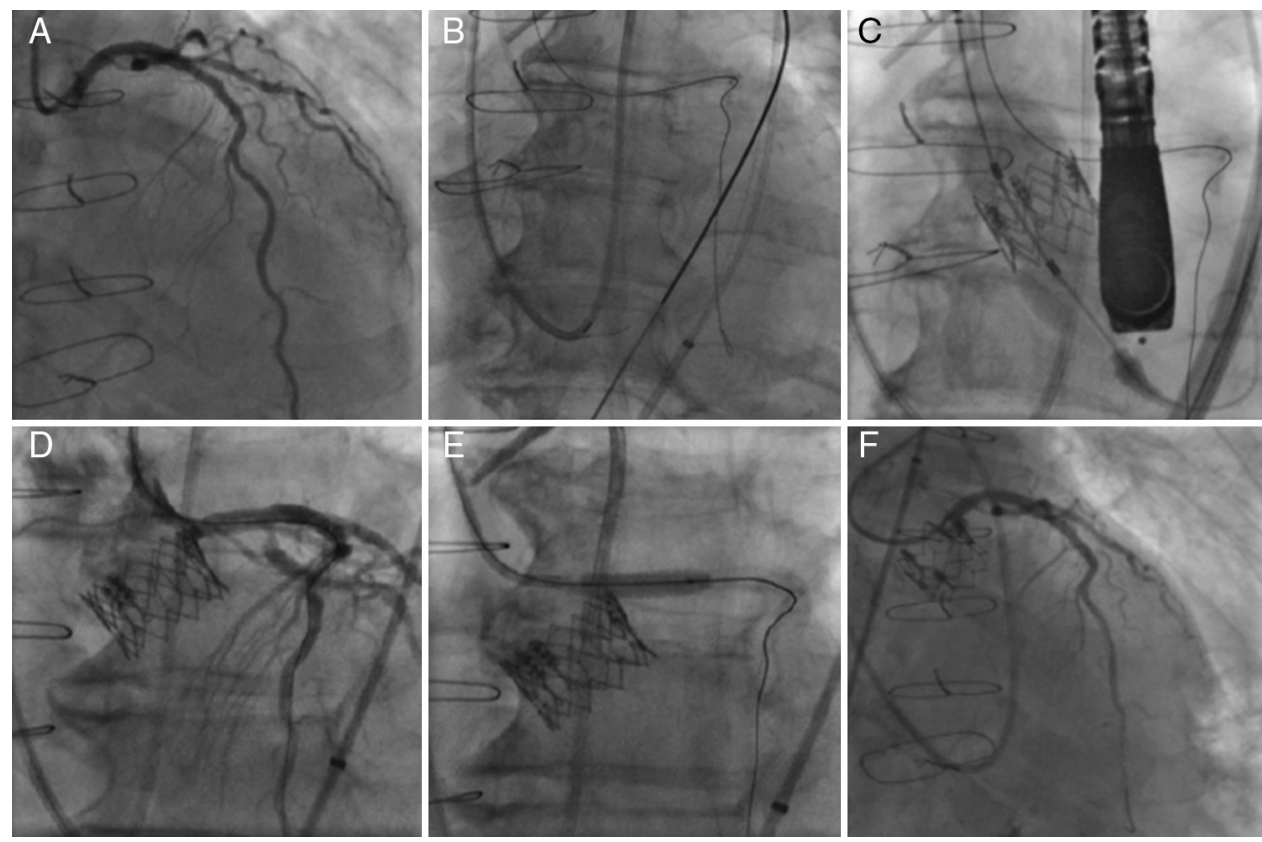

Figure 2 Left coronary artery (LCA) angiography before deployment of the transcatheter valve (A). LCA protection with an extra-support Wiggle guidewire ${ }^{\mathrm{TM}}(\mathrm{B})$. Image showing the deployment of the transcatheter valve $(\mathrm{C})$. Angiography showing partial ostial obstruction of the LCA after the transcatheter valve implantation (D). Pre-dilatation of the left main coronary artery with a $4.0 \times 12 \mathrm{~mm}$ balloon (E). Final angiography after the successful deployment of a drug-eluting stent into the ostium of the left main coronary artery $(\mathrm{F})$. 
ber of patients at risk may confirm if this maneuver should be more widely recommended for patients undergoing TAVI with high-risk features for this complication.

\section{Funding}

H.B.R. is supported by a research PhD grant from "CNPq, Conselho Nacional de Desenvolvimento Científico e Tecnológico - Brasil (246860/2012-0)'”. The other authors declare not receiving any funding for this study.

\section{Conflict of interest}

Dr. Josep Rodés-Cabau is a consultant for Edwards Lifesciences and St-Jude Medical. The rest of the authors have no conflict of interest to disclose.

\section{Bibliografía}

1. Rodes-Cabau J. Transcatheter aortic valve implantation: current and future approaches. Nat Rev Cardiol. 2012;9:15-29.

2. Dvir D, Webb J, Brecker S, et al. Transcatheter aortic valve replacement for degenerative bioprosthetic surgical valves: results from the global valve-in-valve registry. Circulation. 2012;126:2335-44.

3. Ribeiro HB, Nombela-Franco L, Urena M, et al. Coronary obstruction following transcatheter aortic valve implantation: a systematic review. JACC Cardiovasc Interv. 2013;6:452-61.
4. Ribeiro HB, Webb JG, Makkar RR, et al. Predictive factors, management, and clinical outcomes of coronary obstruction following transcatheter aortic valve implantation: insights from a large multicenter registry. J Am Coll Cardiol. 2013;62: 1552-62.

5. Mok M, Dumont E, Doyle D, et al. Transcatheter aortic valve implantation using the slow balloon inflation technique: making balloon-expandable valves partially repositionable. J Card Surg. 2012;27:546-8.

6. Chakravarty T, Jilaihawi H, Nakamura M, et al. Pre-emptive positioning of a coronary stent in the left anterior descending artery for left main protection: a prerequisite for transcatheter aortic valve-in-valve implantation for failing stentless bioprostheses? Catheterization and cardiovascular interventions. Catheter Cardiovasc Interv. 2013;82:E630-6.

Ricardo Allende, Henrique Barbosa Ribeiro, Jean-Michel Paradis, Daniel Doyle, Sergio Pasian, Josep Rodés-Cabau*

Quebec Heart \& Lung Institute, Laval University, Quebec City, Quebec, Canada

* Corresponding author at: Quebec Heart \& Lung Institute, Laval University, 2725 Chemin Sainte-Foy, G1V 4G5 Quebec, QC, Canada.

E-mail address: josep.rodes@criucpq.ulaval.ca

(J. Rodés-Cabau).

http://dx.doi.org/10.1016/j.acmx.2014.04.005

\section{Pericarditis por cristales de colesterol en un paciente con artritis reumatoide}

\section{Cholesterol crystals pericarditis in a patient with rheumatoid arthritis}

\section{Sr. Editor,}

La pericarditis por colesterol es una forma infrecuente de enfermedad pericárdica caracterizada por la presencia de numerosos cristales microscópicos de colesterol en el líquido pericárdico ${ }^{1,2}$. El $49 \%$ de los casos de enfermedad pericárdica son idiopáticos, el resto se relaciona con insuficiencia renal crónica, hipotiroidismo, tuberculosis, artritis reumatoide, insuficiencia cardiaca, infarto de miocardio, carcinomas metastásicos y en ocasiones con poliquistosis renal $^{3}$. La presentación puede ser subclínica y las manifestaciones inespecíficas. En raras ocasiones se manifiesta como pericarditis constrictiva o taponamiento cardiaco, y este último puede representar una urgencia cardiológica que requiere tratamiento inmediato ${ }^{4}$.

Mujer de 55 años con diabetes tipo 2 tratada con hipoglucemiantes por vía oral. Cuatro años antes se le diagnosticó artritis reumatoide $(A R)$ y recibió metotrexato. Este se suspendió 2 meses antes de su ingreso. Inicia su padecimiento con aumento progresivo del perímetro abdominal, edema en miembros inferiores y disnea de medianos esfuerzos que progresó hasta ortopnea y disnea paroxística nocturnas. Acudió a recibir atención médica a su hospital general de zona en Tapachula Chiapas, donde se detectó por ecocardiografía derrame pericárdico y fue referida a nuestra unidad. Ingresó en urgencias del hospital de cardiología con presión arterial de $80 / 60 \mathrm{mmHg}$, frecuencia cardiaca de $150 \mathrm{ppm}$, frecuencia respiratoria de $24 \mathrm{rpm}$, y saturación de oxígeno del $92 \%$. A la exploración física se encontró paciente neurológicamente íntegra, con palidez generalizada de tegumentos, regular estado de hidratación, signo de Kussmaul positivo, los ruidos cardiacos disminuidos en intensidad y aumentados en frecuencia, sin soplos. Los campos pulmonares estaban ventilados sin estertores, en el abdomen reflujo hepatoyugular presente. Las extremidades sin edema. El ecocardiograma transtorácico demostró derrame pericárdico de $1,200 \mathrm{cc}$ sin otra enfermedad asociada. Se realizó pericardiocentesis y se drenaron 1,200 cc de líquido amarillento con $\mathrm{pH}$ de 9 , proteínas totales $4.5 \mathrm{~g} / \mathrm{d}$, DHL $515 \mathrm{UI} / \mathrm{L}$, sin leucocitos. El cultivo bacteriano fue negativo. Las pruebas de laboratorio mostraron glucosa $155 \mathrm{mg} / \mathrm{dL}$, urea $14 \mathrm{mg} / \mathrm{dL}$, creatinina $0.7 \mathrm{mg} / \mathrm{dL}$, sodio $110 \mathrm{~mol} / \mathrm{L}$, potasio $4 \mathrm{mmol} / \mathrm{L}$, cloro $69 \mathrm{mmol} / \mathrm{L}$, proteínas totales $7.3 \mathrm{~g} / \mathrm{dL}$, globulinas $4.2 \mathrm{~g} / \mathrm{dL}$, albumina $3.1 \mathrm{~g} / \mathrm{dL}$, ALT $27 \mathrm{UI} / \mathrm{L}$, AST $25 \mathrm{UI} / \mathrm{L}$, amilasa $36 \mathrm{UI} / \mathrm{L}$, DHL $214 \mathrm{UI} / \mathrm{L}$, y colesterol total 